\title{
A framework to evaluate the energy efficiency potential of Kuwaiti homes
}

\author{
B. Jaffar, T. Oreszczyn \& R. Raslan \\ UCL Energy Institute, University College London, UK
}

\begin{abstract}
Energy demand and consumption rates in Kuwait are amongst the highest in the world. This is largely due to a substantial amount of waste and overconsumption of energy in the residential building sector which accounts for almost $60 \%$ of Kuwait's national electrical power generated. In spite of the existence of an Energy Conservation Code of Practice for Buildings, homes in Kuwait continue to be designed and built with little consideration to their climate, consuming significant amounts of electricity. There is a universal dependence among households on air conditioning systems, artificial lighting, and electrical appliances. Rapidly rising consumption rates by this sector are presenting an increasingly critical challenge for the Kuwaiti government, which is struggling to satisfy existing power demands. This paper reviews and discusses the key characteristics of Kuwait's residential sector, and proposes a framework to evaluate the energy efficiency potential of Kuwaiti homes in order to inform policy developments in this field. As there is a significant lack of data about the Kuwaiti housing stock (its building fabric, energy consuming equipment, and occupants' demand for services), the proposed framework suggests that energy use in a number of Kuwaiti homes is first examined, via an investigative case study strategy, before developing a residential building stock model to evaluate the impact and potential of different efficiency measures.
\end{abstract}

Keywords: energy efficiency policy, residential building sector, building stock modelling, Kuwait.

\section{Introduction}

The state of Kuwait depends entirely on oil resources both as a source of national income and for domestic energy requirements. At present, domestic energy demand is increasingly outstripping supply, leading to disturbing power shortages, 
and a diversion, to the domestic market, of oil and gas originally intended for export $[1,2]$. Rising energy consumption poses serious energy security and economic implications in the foreseeable future, especially in light of the country's rapidly growing population and construction rates [3, 4]. Figure 1 illustrates the flow of energy produced, exported and consumed in Kuwait in 2012. As shown, the residential building sector accounts for $60 \%$ of national electricity consumption. This is a significant proportion compared to the world average of around $25 \%$ relative to other sectors [5].

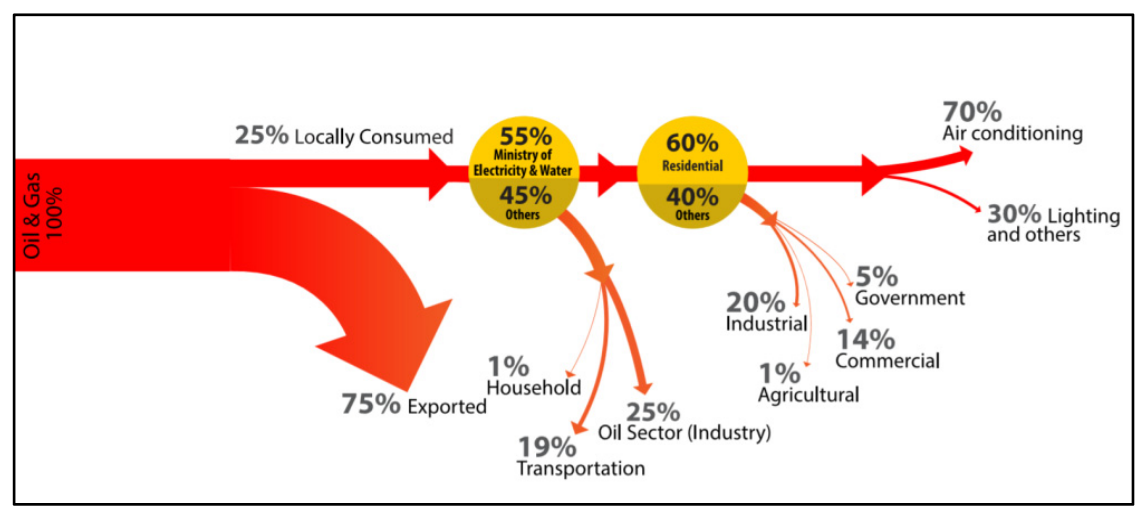

Figure 1: The flow of energy produced, exported and consumed in Kuwait. Source: author generated, based on data from $[6,7]$.

Recognizing the need for improved building energy efficiency to reduce wasteful energy consumption, Kuwait pioneered by being the first country in the Middle East to develop a mandatory Energy Conservation Code of Practice in 1983 applicable to all new and renovated buildings. This code, developed by the Kuwait Institute for Scientific Research (KISR) for the Ministry of Electricity and Water (MEW), specifies minimum thermal resistance for walls, roofs, size and quality for glazing, and performance standards for air-conditioning (AC) and lighting systems [8]. The 1983 code, however, was only updated in 2010 and more recently in 2014 despite advances in design and construction, technology, and building energy simulation programs over the past four decades. Similarly, although the code has been enforced since 1983, there is very little evidence of its impact in practice; Kuwaiti homes today continue to be designed and built with little consideration to their climate, consuming significant amounts of energy [9-11].

On a general note, energy demand and consumption in the residential sector as a whole is complex, depending on a range of factors including building fabric performance, building systems and their operational features, and occupant behaviour which is driven by elements such as income, energy tariffs, and weather [12-14]. This complexity suggests that the performance of energy efficiency improvements and the expected benefits of energy efficiency policies can be 
subject to a considerable level of uncertainty [15-17]. Similarly, as energy savings represent energy that was not consumed, quantifying such savings is a challenging process, especially as savings cannot be measured in the same manner as energy consumption can [18]. Traditionally bottom-up building physics based modelling methods, such as building stock models, are used to evaluate and quantify energy savings and inform energy efficiency policy developments in this field $[13,19]$.

This paper presents a framework for evaluating the energy efficiency potential of Kuwaiti homes by initially examining energy use in a number of case study homes before developing a residential building stock model. This approach to stock model development is especially useful in the context of Kuwait where there is very limited data available about the existing housing stock (its fabric characteristics, energy consuming equipment, and occupants' demand for services).

At the time of compilation of this paper, the energy monitoring of a number of household case studies was underway. The paper will thus present the rationale behind the proposed framework and will review initial findings regarding the characteristics of the Kuwaiti housing stock. Analysis of monitoring and stock modelling results will be presented in future publications once complete.

\section{Literature review}

\subsection{Factors contributing to unsustainable energy consumption in Kuwait}

After the discovery and exportation of oil in the 1940s, Kuwait witnessed an exceptional period of economic growth, development and construction, which transformed the old traditional settlement into a modern built environment within just a decade [4, 20]. New housing typologies emerged as well as a drastically different way of life from that found in pre-oil Kuwait [20]. Figure 2 highlights the numerous factors contributing to unsustainable energy consumption rates in Kuwait. These primarily include the government's generous welfare and energy subsidy program, a rapid growth in the population and wealth per capita of the population, high rates of construction and the country's harsh summer climatic conditions $[1,9,21]$.

The government's generous energy subsidy programme has created a universal dependence among households on high electricity consumption [22]. First set up in 1962 , this programme today endorses more than $95 \%$ of the cost of energy to the final consumer; residential consumers are charged a flat rate of KD $0.002 / \mathrm{kWh}$ (equivalent to $\$ 0.01$ at the time of writing) of the electricity generation cost of KD $0.047 / \mathrm{kWh}$ (equivalent to \$0.16) [2]. Such electricity rates, which are among the lowest in the world, have remained unchanged for over 50 years, despite increases in production and generation costs and the opportunity cost of the primary source on international markets [23]. Such tariffs are also undermining efficiency incentives, trigging wasteful consumer behaviour and an intrinsic demand for bigger homes designed with little or no consideration to energy conservation $[24,25]$. 
In addition, Kuwait's relatively high annual population growth rate of $2.4 \%$ [26] has resulted in an increased demand for housing, which has in turn translated directly into an increased demand for energy [2]. The current population of 3.8 million (of which 1.2 million are Kuwaiti nationals and 2.6 million expatriates, [27]) is estimated to reach 5.9 million by 2030 [26]. The Kuwaiti Government has thus highlighted, in its latest National Development Plan, the goal of establishing six new residential cities providing more than 70,000 new housing units over the next five years [28]. Although such ambitious projects are essential to meet the demands of a rapidly growing population, they will require significant additional production of electricity [2, 21].

Furthermore, Kuwait's hot and dry desert climate, with summer temperatures in access of $45^{\circ} \mathrm{C}$, is another key factor contributing to high domestic consumption. Peak summer electricity demand in Kuwait has been rising by 6-8\% per year, with total demand increasing from 6,750 MW in 2001 to approximately $11,900 \mathrm{MW}$ in 2011 [7,29]. As the current installed capacity (14,702 MW [7]) is very close to peak summer demand, supply increases have often struggled to keep pace, resulting in power cuts and outages. The MEW has thus estimated that an additional 10,000 MW of installed electrical generation capacity will be needed by $2020[7,28]$.

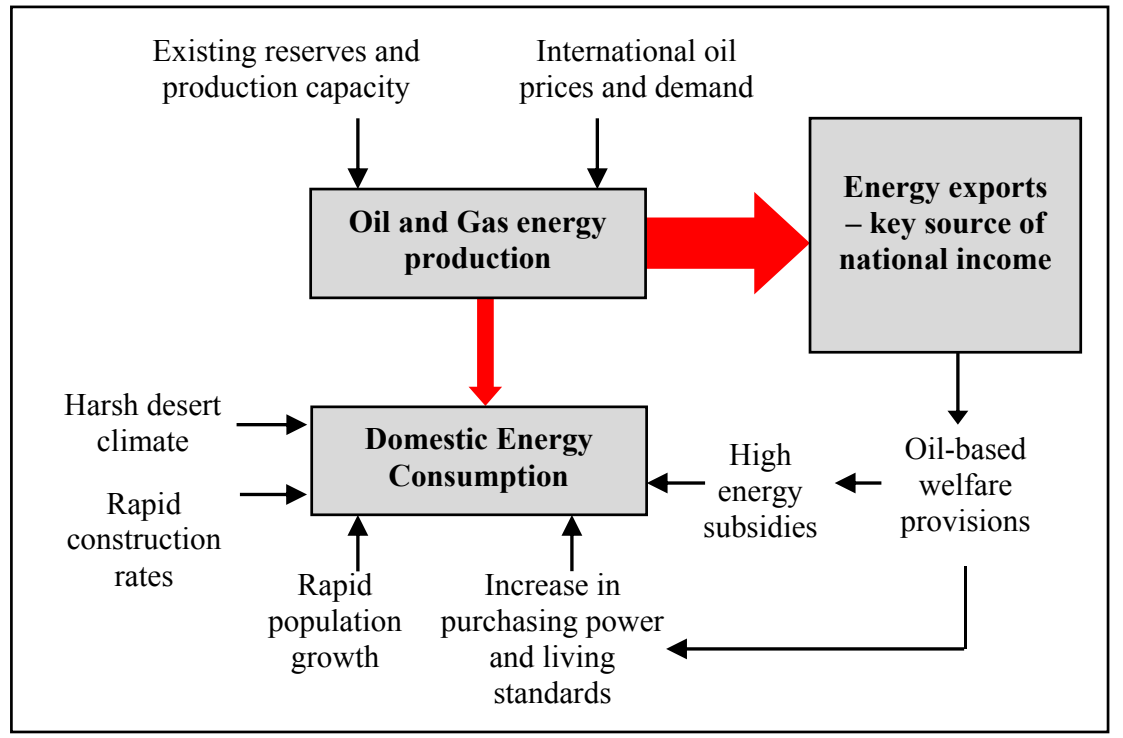

Figure 2: Factors influencing energy production and consumption in Kuwait. Source: author generated.

\subsection{The role of energy demand modelling in informing energy efficiency policy developments in buildings}

At present, the overarching aim of energy policy is to achieve quick and profound reductions in carbon dioxide $\left(\mathrm{CO}_{2}\right)$ emissions and to ensure that the energy supply 
system is sustained [30]. Ever since the first oil crisis in the 1970s, energy efficiency has become a widely accepted element of overall energy policy [31]. Buildings, which are among the largest consumers of energy, have and continue to be a key target for energy efficiency policy worldwide [18]. To promote an enabling environment for efficiency improvements in buildings and enhance motivation to adopt energy efficient technologies a variety of policy instruments are used [18]. Selection of instruments depends on the appropriateness of the instrument to its context, how it is designed, implemented, and evaluated [32]. Policy evaluation in particular, is an important element allowing for assessments to be made that can better inform future improvements in the policy development process [33-35]. A variety of measurement and verification tools are used to evaluate energy efficiency policy interventions and quantify energy savings in residential buildings of which energy demand modelling, in the form of building stock modelling, is one $[13,19]$.

Building stock models include bottom-up physics based models, that are able to estimate baseline energy consumption of an existing stock and quantitatively assess and predict the impact of energy efficiency measures on future energy demand $[13,19]$. Due to the size and complexity of the residential housing stock, the archetype technique is often used for stock aggregation. Establishing archetype definitions for each major class of house and then scaling these up according to the number of houses for that archetype thus allows for analysis of the existing housing stock [19, 36, 37]. Archetypes however are based on a number of fundamental assumptions, exclusions and simplifications that can significantly impact a stock model's predictive power and output results $[19,36,38]$. Normative occupant behavior is assumed and factors such as construction quality, commissioning and fit out, as well as equipment added by occupants and pattern of use of the building including control and maintenance of systems are not considered [19, 39]. Consequently energy research has frequently shown a discrepancy between energy predictions from models and measured/real building energy use data $[15,16,40,41]$. As energy models are increasingly being used in the design and evaluation of energy efficiency policies, it's imperative that policymakers understand this discrepancy (sometimes referred to as the "performance gap") and its consequent impact on achieving carbon reductions targets $[19,40]$.

In response to the above mentioned issues, the significance of improving the model development process and accounting for certain correction factors to reduce differences between actual and theoretical energy savings is increasingly being recognized $[19,40]$. This study thus seeks to improve the reliability of stock model predictions by initially adopting a case study strategy to better understand the complex determinants of building energy performance. Exploring, understanding and explaining the mechanisms operating within a specific context can assist in drawing more informed inferences and extrapolations about other settings and cases. This reasoning forms the basis of the proposed framework for evaluating the energy efficiency potential of Kuwaiti homes. 


\subsection{Characteristics of the Kuwaiti housing stock}

After the implementation of the First Master Plan for Kuwait in 1952, residential suburbs were categorized into two types: 1) the ideal residential suburbs or 'manatiq namuthajiya', 2) the commercial suburbs or 'manatiq istithmariya'. Most Kuwaitis moved into the ideal residential suburbs which are designed to be selfsufficient, each containing a central shopping plaza with a cooperative supermarket, a health clinic, police station, and public schools. Each suburb contains approximately four to ten unit blocks, with each block housing a minimum of 100 single family houses. Commercial suburbs however consist of mid-high rise apartment buildings, and house mainly the expatriate population.

According to the Public Authority for Civil Information's (PACI) latest Housing and Building Statistics [42], there are a total of 187,730 buildings across Kuwait, of which residential buildings represent a significant portion (figure 3). Housing consists primarily of villas (in the form of single family detached houses), flats in mid-high rise apartments, traditional pre-1940s courtyard housing units, and palaces. The main residential 'building' type present today is the single family detached house of which there are two distinct variations, namely government houses and private villas, where the vast majority of Kuwaiti nationals live. Government houses are designed and built by the Public Authority for Housing Welfare (PAHW - the sole agency responsible for setting and implementing national housing policies), while private villas are often partly financed by the PHAW but designed and built by the homeowner themselves. Flats in mid-high rise apartment buildings however, are the main residential 'unit' type, and house the majority of the expatriate population.

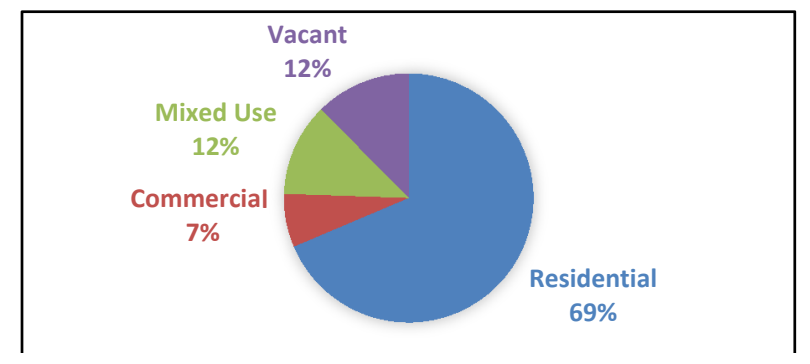

Figure 3: Kuwait's building mix, 2013. Source: PACI [42].

Table 1: Number of residential buildings and units in Kuwait, 2013. Source: [42].

\begin{tabular}{|c|c|c|c|c|c|c|}
\hline \multicolumn{2}{|c|}{ Villas } & \multirow{2}{*}{$\begin{array}{c}\text { Apartment } \\
\text { blocks }\end{array}$} & \multicolumn{2}{|c|}{ Flats } & \multirow{2}{*}{$\begin{array}{c}\text { courtyard } \\
\text { houses }\end{array}$} & \multirow[t]{2}{*}{ Palaces } \\
\hline Government & Private & & Government & Private & & \\
\hline 56,536 & 49,228 & \multirow[b]{2}{*}{10669} & 1088 & 169,727 & \multirow[b]{2}{*}{20,984} & \multirow[b]{2}{*}{47} \\
\hline \multicolumn{2}{|c|}{105,764} & & \multicolumn{2}{|c|}{170,815} & & \\
\hline
\end{tabular}


In order to evaluate the energy efficiency potential of any housing stock, it is essential to first examine the characteristics of that housing stock including the number and type of dwellings built over time, their size, form, construction fabric, building services, and metered energy consumption data. To gather information about the Kuwaiti housing stock a number of sources were used including housing statistics from PACI, building archival records from Kuwait's Central Statistical Bureau (CSB), and building codes including the MEW's Energy Conservation Code and Kuwait Municipality's (KM) Building Code.

Collecting data about the Kuwaiti housing stock proved to be a challenging task as there is little organised and coherent data available about the Kuwaiti residential sector, its evolution, development, and energy consumption. No detailed housing stock survey describing the composition of the stock, dwelling sizes, dwelling form and fabric characteristics, type of building services and appliances used, and dwelling thermal characteristics/performance, has been undertaken to date. Building census data from PACI and CSB provide limited information regarding dwelling type, numbers and year of build only.

This paper presents data about the housing stock based on year of build and various corresponding events that have impacted the built environment at the time. Such events include modifications in municipality building codes (1996, 2000 and 2002 to increase built up floor area), the MEW's energy conservation code (1983, 2010 and 2014) and events such as changes to the national housing welfare scheme by the PAHW (today the PAHW provides a standard housing model for all citizens, however from 1967-1984 housing welfare was based on income stratification in which two different housing models were provided based on citizen income). Such events were mapped onto a timeline that also depicted the number and type of dwellings at that time thus assisting in the segmentation of the Kuwaiti housing stock for further research (Table 2, figure 4).

Table 2: Typical plot and built up area sizes of housing units in Kuwait. Source: author generated based on a collection of data from KM, PAHW visits.

\begin{tabular}{|c|c|c|c|}
\hline House type & $\begin{array}{l}\text { Number } \\
\text { of units }\end{array}$ & $\begin{array}{l}\text { Approximate } \\
\text { plot size }\end{array}$ & $\begin{array}{l}\text { Approximate floor } \\
\text { area/dwelling }\end{array}$ \\
\hline Villas & 105,764 & & \\
\hline $\begin{array}{l}\text { Government Low income housing 1967- } \\
1984 \text { ( } 2 \text { floors) }\end{array}$ & 27,626 & $250 \mathrm{~m}^{2}-750 \mathrm{~m}^{2}$ & $350-400 \mathrm{~m}^{2}$ \\
\hline $\begin{array}{c}\text { Government - Middle income housing } \\
1967-1984 \text { (2 floors) }\end{array}$ & 4000 & $400 \mathrm{~m}^{2}-750 \mathrm{~m}^{2}$ & $500 \mathrm{~m}^{2}$ \\
\hline $\begin{array}{c}\text { Government housing } 1984-\text { present }(2 \\
\text { floors) }\end{array}$ & 24,910 & $400 m^{2}-600 m^{2}$ & $400 \mathrm{~m}^{2}-500 \mathrm{~m}^{2}$ \\
\hline $\begin{array}{c}\text { Private villas ( } 2-3 \text { floors plus basement } \\
\text { option) }\end{array}$ & 49,228 & $350 \mathrm{~m}^{2}-1000 \mathrm{~m}^{2}$ & $400 \mathrm{~m}^{2}-1400 \mathrm{~m}^{2}$ \\
\hline Apartments & 170,815 & & \\
\hline Government apartments $1980 \mathrm{~s}$ & 1088 & $\begin{array}{l}\text { large complex with many } \\
\text { flats/floor }\end{array}$ & $350 \mathrm{~m}^{2}$ \\
\hline Government apartment future plans & $\begin{array}{c}\text { Under } \\
\text { planning }\end{array}$ & $\begin{array}{l}\text { Low-rise } 5 \text { storey building } \\
\text { ( } 1 \text { flat/floor) }\end{array}$ & $400 \mathrm{~m}^{2}$ \\
\hline Residential apartments & 169,727 & In excess of $400 \mathrm{~m}^{2}$ & $70 \mathrm{~m}^{2}-250 \mathrm{~m}^{2}$ \\
\hline \multirow[t]{2}{*}{ Pre-1940s courtyard houses } & 20,984 & & \\
\hline & - & $100-150 \mathrm{~m}^{2}$ & $100-150 \mathrm{~m}^{2}$ \\
\hline \multirow[t]{2}{*}{ Palaces } & 47 & & \\
\hline & - & In excess of $1000 \mathrm{~m}^{2}$ & In excess of $3000 \mathrm{~m}^{2}$ \\
\hline
\end{tabular}


Estimations of the thermal characteristics of homes was made by combining data from the year of build with the relative thermal regulations from the MEW's energy code guidelines, and estimations of the relative size of dwellings was made by combining year of build data with the relative KM building code guidelines of the time. Similarly, as no data regarding the Kuwaiti housing stock's overall energy consumption was readily available, the researcher met with key professionals at the MEW to obtain and tabulate this information (table 3). As table 3 illustrates, Kuwaiti dwellings consume a significantly greater amount of energy relative to the average UK dwelling (considering however that Kuwaiti domestic energy use, unlike in the UK, is predominantly electricity).

Table 3: Average energy consumption by flats and villas in Kuwait, 2009. Source: $[43,44]$.

\begin{tabular}{|c|c|c|c|c|c|c|}
\hline \multicolumn{5}{|c|}{ KUWAIT } & \multicolumn{2}{|c|}{ UK (2013) } \\
\hline \multirow[b]{2}{*}{$\begin{array}{c}\text { Dwelling } \\
\text { type }\end{array}$} & \multirow[b]{2}{*}{$\begin{array}{c}\text { Number } \\
\text { of } \\
\text { dwellings }\end{array}$} & \multicolumn{3}{|c|}{ Electricity consumed } & \multirow[b]{2}{*}{$\begin{array}{l}\text { Average kWh/ } \\
\text { dwelling/ } \\
\text { annum }\end{array}$} & \multirow[b]{2}{*}{$\begin{array}{c}\text { Average } \\
\mathbf{k W h} / \mathbf{m}^{2} / \\
\text { dwelling/ } \\
\text { annum }\end{array}$} \\
\hline & & Share & $\begin{array}{c}\text { Average } \\
\text { kWh/ } \\
\text { dwelling/ } \\
\text { annum }\end{array}$ & $\begin{array}{c}\text { Average } \\
\mathrm{kWh} / \mathrm{m}^{2} / \\
\text { dwelling/ } \\
\text { annum }\end{array}$ & & \\
\hline Villas & 105,764 & $88 \%$ & 145,444 & 264 & $\begin{array}{c}4,170 \text { (electricity) } \\
14,829 \text { (gas) }\end{array}$ & \\
\hline Flats & 170,815 & $12 \%$ & 20,278 & 127 & Total - 18,999 & 209 \\
\hline
\end{tabular}

Note: Villas include both private villas and government houses. Average $\mathrm{kWh} / \mathrm{m}^{2} /$ dwelling for villas in Kuwait has been calculated based on an approximate floor area of $550 \mathrm{~m}^{2}$, and for flats $160 \mathrm{~m}^{2}$. Average $\mathrm{kWh} / \mathrm{m}^{2} / \mathrm{dwelling}$ in the UK has been calculated based on an average dwelling size of $91 \mathrm{~m}^{2}$ [45].

\section{An approach to designing a framework for evaluating the energy efficiency potential of Kuwaiti homes}

In the end-use energy demand research field past academic studies have often been unable to provide relevant solutions to real and practical matters $[15,16,40,46]$. Although for decades researchers have demonstrated the energy saving potential of different technologies/measures in reality actual energy use has varied between design and modeled predictions with limited understanding of the reasons for such discrepancies [16, 17, 47]. Researchers have highlighted that this is due to the nature of research undertaken and the prevalent positivist approach adopted within the field isolating individual factors and excluding the influence of people $[15,40]$. Recently interest in human-centered aspects of energy has increased, and many have criticized this predominant positivist approach $[15,40,46]$.

The framework for evaluating the energy efficiency potential of Kuwaiti homes proposes that energy use in a number of representative homes is first examined, via an investigative case study strategy, before developing a residential building stock model. It is hoped that this approach improves the reliability of stock model predictions by providing valuable empirical data to inform the description of model input parameters associated with three key areas: 
1. Occupant behaviour and requirements

2. Dwelling form and fabric

3. Building systems

The purpose of the case study approach presented in this paper is exploratory; to gain insight into the mechanisms operating within a specific context and thus better understand the complex determinants of building energy performance. Such insight can in turn assist in drawing more informed inferences and extrapolations about other cases and settings (establishing 'evidence based' assumptions) to substantiate the stock modelling development process.

The case study strategy involves multiple case studies to allow for case comparisons and preliminary suggestive generalizations. A typical case sampling approach is used to present a profile of representative cases that can inform stock model archetypes. The Kuwaiti housing stock is segmented according to vintage (period of construction) and dwelling type (figure 4), and different case study homes are selected from within these categories. Key dwelling types considered include the single family detached villa, of which there are two distinct variations (government and private) and flats in mid-high rise apartment blocks. Traditional courtyard houses and palaces are not considered for examination as they represent a relatively small and declining percentage of the existing stock and its energy use. Similarly, the three key periods of construction selected correspond to the development and revisions of the MEW's Energy Conservation Code; pre-code (1952-1983), post code (1983-2010), and post code revisions (2010-2014).

As the subject of energy use within residential homes in Kuwait is not well understood, the case study strategy will draw on multiple sources of data to enhance data corroboration and allow for more robust results. These include secondary data sources such as utility bills and floor plans as well as primary sources such as occupant interviews and monitoring of indoor environmental conditions. The case study strategy will thus attempt to integrate knowledge of a home's physical systems (via monitoring) with knowledge of the social practices (via interviews) and utilize the totality of this information to inform the stock modeling development process.

Household floor plans and past utility bills will be reviewed prior to collecting primary data (via occupant interviews and monitoring) to gain a general understanding of the home's energy consumption. During the primary data collection process, two sets of occupant interviews will be undertaken. The first set will take place prior to the monitoring exercise to allow for an understanding of household background information including occupants' daily routines and activities. The second set of interviews will take place after the monitoring period to assist with the analysis of monitored data by documenting occupant experiences and any changes that may have occurred to energy using practices during the monitoring period. The monitoring exercise will involve recording internal temperature, relative humidity and lighting in different rooms with minimum influence by the researcher. HOBO data loggers will be installed, and the monitoring period will last for a period of one year to determine the effects of seasonal variations on energy consumption. 


\begin{tabular}{|c|c|c|}
\hline $\begin{array}{c}\text { Period of } \\
\text { construction/vintage }\end{array}$ & \multicolumn{2}{|c|}{ Dwelling type } \\
\hline $\begin{array}{c}\text { 1952-1984 } \\
\text { 1952 Kuwait's first } \\
\text { master plan } \\
\text { 1967-1984 PAHW } \\
\text { allocates housing based } \\
\text { on income stratifications }\end{array}$ & \multirow{2}{*}{$\begin{array}{l}\text { Private villas } \\
\text { Occupied mainly by Kuwaiti } \\
\text { families. } \\
\text { Villas range in design and } \\
\text { form, are fully detached, } \\
\text { consist of } 2-3 \text { floors, and a } \\
\text { number of sleeping and living } \\
\text { spaces as well as staff } \\
\text { accommodation. }\end{array}$} & \multirow{2}{*}{$\begin{array}{l}\text { Government houses } \\
\text { Occupied by Kuwaiti families. } \\
\text { Houses consist of } 2 \text { levels, are } \\
\text { fully detached, and built based } \\
\text { on a standard size, shape and } \\
\text { structure. All houses consist of a } \\
\text { number of sleeping, and living } \\
\text { spaces as well as staff } \\
\text { accommodation }\end{array}$} \\
\hline $\begin{array}{c}\text { 1984-2010 } \\
\text { 1983 MEW Energy } \\
\text { Conservation Code } \\
\text { 1984 PAHW Equal } \\
\text { housing welfare } \\
\text { 1985 KM first set of } \\
\text { building regulations } \\
\text { 1996,2000, 2002 KM } \\
\text { increased permissible } \\
\text { house area }\end{array}$ & & \\
\hline $\begin{array}{l}\mathbf{2 0 1 0 - 2 0 1 4} \\
\text { 2010 MEW code } \\
\text { revisions } \\
\text { 2014 MEW code } \\
\text { revisions }\end{array}$ & \multicolumn{2}{|c|}{$\begin{array}{l}\text { Occupied mainly by the expatriate } \\
\text { population in Kuwait. } \\
\text { Blocks vary in external design, } \\
\text { form, construction and height } \\
\text { The number of flats per block can } \\
\text { range from 5-20 depending on the } \\
\text { standard, quality, and governorate } \\
\text { in which they are built. }\end{array}$} \\
\hline
\end{tabular}

Figure 4: Segmentation of the Kuwaiti housing stock by vintage and type. Source: author generated.

\section{Conclusion}

As energy consumption rates in Kuwaiti homes are amongst the highest in the world, effective and appropriate energy efficiency policy interventions are crucial. The selection of policy instruments depends on the appropriateness of the instrument to its context, how it is designed, implemented, and evaluated. Policy evaluation is an especially important element allowing for assessments to be made that can better inform future improvements in the policy development process. Building stock models are traditionally used as a tool to evaluate energy efficiency policy interventions and quantify energy savings in residential buildings. Through the use of representative archetypes, such models are able to estimate the energy consumption of an existing stock and assess the impact of technical and economic efficiency strategies and technologies on future energy demand. However due to the size and complexity of energy use within the housing stock, such models, are based on a number of fundamental assumptions, exclusions and simplifications that significantly impact their predictive power and output results.

This paper proposes a framework that seeks to improve the reliability of stock model predictions by initially adopting a case study strategy to better understand the complex determinants of building energy performance. It is hope that this will enable a better assessment of the impact of efficiency measures on energy demand and thus better inform policy developments in this field. This approach is 
especially valuable in the context of Kuwait where empirical data about the residential stock, its fabric, energy consuming equipment and occupant demand for services is largely unavailable.

\section{References}

[1] Hertog, S., and Luciani, G., Energy and sustainability in the GCC. Kuwait programme on development, governance and globalization in the Gulf states, LSE, London, 2009, http://www2.lse.ac.uk/government/research/resgroups/kuwait/documents/ Hertog\%20paper.pdf

[2] Wood, M., and Alsayegh, O., Impact of oil prices, economic diversification policies, and energy conservation programs on the electricity and water demands in Kuwait, Energy Policy, (66) 144-156, 2014

[3] Lahn, G., Stevens, P., and Preston, F., Saving oil and gas in the Gulf. London: A Chatham House Report. 2013, http://www.chathamhouse.org/publications/papers/view/193884

[4] Alshalfan, S., The right to housing in Kuwait: An urban injustice in a socially just system, Kuwait programme on development, governance and globalization in the Gulf states, LSE, London, 2013, http://www.lse.ac.uk/government/research/resgroups/kuwait/documents/T he-right-to-housing-in-Kuwait.pdf $>$

[5] Deloitte, Energy demand: the future of GCC energy efficiency, Managing scarcity for the future, whitepaper number 4, 2011, http://www.deloitte.com/assets/DcomLebanon/Local\%20Assets/Document s/Energy_and_resources/E\&R\%20whitepaper\%204\%20energy\%20efficie ncy\%20V2.pdf

[6] Ministry of Oil (MOO), Local energy consumption by sector, Kuwait, http://www.moo.gov.kw

[7] Ministry of Electricity and Water (MEW), Statistical data book 2012 Electricity and water, 2012

[8] Ministry of Electricity and Water (MEW), Energy conservation program: Code of practice. Kuwait, 2014, http://www.mew.gov.kw/media/The $\% 20$ Code $\% 20$ \%20Master\%20copy.pdf

[9] Alotaibi, S., Energy consumption in Kuwait: prospects and future approaches. Energy Policy, 39, pp. 637-643 2011

[10] Reiche, D., Energy policies of Gulf Cooperation Council (GCC) countries - possibilities and limitations of ecological modernisation in rentier states. Energy Policy, 38(5), pp. 2396-2403. 2010

[11] Maheshwari, G.P., Al-Mulla, A., and Al-Hadban, Y., Energy management program for the state of Kuwait. International Journal of Energy Technology and Policy, 7(1), pp. 95-112, 2009

[12] Wei, Y., Baizhan L, Yarong, L., Meng, L., Analysis of a residential building energy consumption demand model. Energies, 4, pp. 475-487, 2011 
[13] Swan, L.G., and Ugursal, V., I., Modelling of end-use energy consumption in the residential sector: A review of modelling techniques. Renewable and Sustainable Energy Reviews, 13, pp. 1819-1835, 2009

[14] Isaac, M., and Van Vuuren, D.P., Modelling global residential sector energy demand for heating and air conditioning in the context of climate change. Energy Policy, 37, pp. 507-521, 2009.

[15] Hamilton, I., Summerfield, A., Lowe, R., Ruyssevelt, P., Elwell, C.A., Oreszczyn, T., Energy epidemiology: a new approach to end-use energy demand research. Building Research \& Information, 41(4), pp. 482-497, 2013

[16] Oreszczyn, T., and Lowe, R., Challenges for energy and building research: objectives, methods and funding mechanisms. Building Research \& Information, 38(1), pp. 107-122, 2010

[17] Lutzenhiser, L., and Shove, E., Contracting knowledge: the organizational limits to interdisciplinary energy efficiency research and development in the US and the UK. Energy Policy, 27, pp. 217-227, 1999

[18] United Nations Environment Programme (UNEP), Promoting energy efficiency in buildings: Lessons learned from international experience USA, 2010 , http://www.thegef.org/gef/sites/thegef.org/files/publication/EEBuilding WEB.pdf

[19] Kavgic, M., Mavrogianni, A., Mumovic, D., Summerfield, A., Stevanovic, Z., Djurovic-Petrovic, M., A review of bottom-up building stock models for energy consumption in the residential sector. Building and Environment, 45, pp. 1683-1697. 2010

[20] Mahgoub, Y., Architecture and the expression of cultural identity in Kuwait. The Journal of Architecture, 12(2), pp. 165-182, 2007

[21] Ramadhan, M., and Hussain, A., Kuwait energy profile for electrical power generation. Strategic planning for energy and the environment, 32(1), pp. 18-25, 2012

[22] Krane, J., 2013. Stability versus sustainability: Energy policy in the gulf monarchies. Electricity policy research group working paper 1302, Cambridge working paper in Economics 1304. University of Cambridge

[23] Alsayegh, O., Restructuring Kuwait's electrical power system: Mandatory or optional? World Academy of Science, Engineering and Technology, 21, pp. 513-517, 2008

[24] Al-ajmi, F., and Loveday, D.L., Indoor thermal conditions and thermal comfort in air-conditioned domestic buildings in the dry-desert climate of Kuwait. Building and Energy, 45, pp. 704-710, 2010

[25] Al-Mumin, A., Khattab, O., Sridhar, G., Occupants' behavior and activity patterns influencing the energy consumption in the Kuwaiti residences. Energy and Buildings, 35, pp. 549-559, 2003

[26] Euromonitor International. 2013. Kuwait in 2030: The Future Demographic. May 2013, http://www.euromonitor.com/kuwait-in-2030the-future-demographic/report 
[27] Public Authority for Civil Information (PACI), Population statistics, 2013, http://www.paci.gov.kw/en/

[28] Oxford Business Group, The Report - Kuwait, 2012, http://www.oxfordbusinessgroup.com/product/report/report-kuwait-2012

[29] Ministry of Electricity and Water (MEW), Statistical data book 2001 Electricity and water. 2001

[30] Oreszczyn, T., and Lowe, R., Regulatory standards and barriers to improved performance for housing. Energy Policy, 36, pp. 4475-4481, 2008

[31] Janssen, R., Energy efficiency policy explained: An introduction. London, 2008, http://www.helio-international.org/EEPolicyExplained.pdf

[32] Koeppel, S., Ürge-Vorsatz, D., Mirasgedis, S., Is there a silver bullet? A comparative assessment of twenty policy instruments applied worldwide for enhancing energy efficiency in buildings. ECEEE 2007 Summer Study. Saving Energy - Just do it! eds. Attali, S., and Tillerson, K., France, pp. 369-380. 2007

[33] Constantinescu T., and Janssen, R., Evaluating energy efficiency policies and measures. ECEEE 2007 Summer Study. Saving Energy - Just do it! eds.

Attali, S., and Tillerson, K., France, pp. 709-717, 2007

[34] Vine, E., Strategies and policies for improving energy efficiency programs: Closing the loop between evaluation and implementation. Energy Policy, 36, pp. 3872-3881, 2008

[35] Morvaj, Z., and Bukarica, V., Energy efficiency policy, Energy Efficiency, ed. Jenny Palm, ISBN: 978-953-307-137-4, InTech, 2012, http://cdn.intechopen.com/pdfs-wm/11461.pdf

[36] Raslan, R., and Mavrogianni, A., Developing a national stock model to support building energy efficiency research and policy in Egypt. Building Simulation Cairo 2013, Towards Sustainable and Green Life. Cairo, 23-24 June 2013. Egypt, 2013

[37] Famuyibo, A., A., Duffy, A., and Strachan, P., Developing archetypes for domestic dwellings - An Irish case study. Energy and Buildings, 50, pp. 150-157, 2012

[38] Summerfield, A., Raslan, R., Lowe, R.J., and Oreszczyn, T., How useful are building energy models for policy? A UK Perspective. $12^{\text {th }}$ Conference of International Building Performance Simulation Association: Proceedings of Buildings Simulation 2011. Sydney, 14-16 November, pp. 2477-2482, 2011

[39] Wood, G., and Newborough, M., Dynamic energy-consumption indicators for domestic appliances: environment, behavior and design. Energy and Buildings, 35, pp. 821-841, 2003

[40] Oreszczyn, T., Hamilton, I., Laurent, M., Allibe B., Tigchelaar, C., Galvin, R., Back to reality: How domestic energy efficiency policies in four European countries can be improved by using empirical data instead of normative calculation. ECEEE [European Council for Energy Efficiency Economy] 2013 summer study - Rethink, renew, restart: ECEEE summer study proceedings. Sweden, pp. 2057-2070, 2013 
[41] Roberts, S., Altering existing buildings in the UK. Energy Policy, 36, pp. 4482-4486, 2008

[42] Public Authority for Civil Information (PACI), Housing and Building Statistics, 2013, http://www.paci.gov.kw/en/

[43] Ministry of Electricity and Water (MEW), Residential sector energy consumption 2009, Information centre and statistics department, Kuwait. 2014

[44] Department of Energy and Climate Change (DECC), Energy consumption in the UK 2014, 2014, https://www.gov.uk/government/uploads/system/uploads/attachment_data/ file/338662/ecuk chapter_3 domestic_factsheet.pdf

[45] Department of Energy and Climate Change (DECC), National energy efficiency data framework, June 2013,

https://www.gov.uk/government/uploads/system/uploads/attachment_data/ file/209089/National_Energy Efficiency Dataframework June 2013 Part_I.pdf

[46] Chiu, L.F., Lowe, R., Raslan, R., Altamirano-Medina, H., Wingfield, J., A socio-technical approach to post-occupancy evaluation: interactive adaptability in domestic retrofit. Building Research \& Information, 42(5), pp. 574-590, 2014

[47] Shove, E., 1998. Gaps, barriers and conceptual chasms: theories of technology transfer and energy in buildings. Energy Policy, 26(15), pp. 1105-1112 